\title{
Molecular characterization of Nocardiopsis species from Didwana dry salt lake of Rajasthan, India
}

\author{
Khushbu Parihar \\ Mycology and Microbiology Laboratory, Department of Botany, JNV University, Jodhpur-342001 \\ (Rajasthan), India \\ Alkesh Tak \\ Mycology and Microbiology Laboratory, Department of Botany, JNV University, Jodhpur-342001 \\ (Rajasthan), India

\section{Praveen Gehlot*} \\ Mycology and Microbiology Laboratory, Department of Botany, JNV University, Jodhpur-342001 \\ (Rajasthan), India \\ Rakesh Pathak \\ ICAR-Central Arid Zone Research Institute, Jodhpur- 342003 (Rajasthan), India \\ Sunil Kumar Singh \\ ICAR-Central Arid Zone Research Institute, Jodhpur- 342003 (Rajasthan), India \\ *Corresponding author. Email: drpg73@rediffmail.com
}

\section{Article Info}

https://doi.org/10.31018/

jans.v13i1.2574

Received: February 10, 2021

Revised: March 9, 2021

Accepted: March 13, 2021

\section{How to Cite}

Parihar, K. et al. (2021). Molecular characterization of Nocardiopsis species from Didwana dry salt lake of Rajasthan, India. Journal of Applied and Natural Science, 13(1): 396 - 401. https://doi.org/10.31018/jans.v13i1.2574

\begin{abstract}
The genus Nocardiopsis is well known to produce secondary metabolites especially antibacterial bioactive compound. Isolation and characterization of bioactive compounds producing novel isolates from unusual habitats are crucial. The present study was aimed to explore Didwana dry salt lake of Rajasthan state in India for the isolation and characterization of actinomycetes. The isolated actinomycetes isolates were characterized based on culture characteristics, biochemical tests and 16S rRNA gene sequencing. The 16S rRNA gene sequence analysis revealed that all the five isolates inhabiting soil of the said dry salt lake of Didwana, Rajasthan belonged to four species of Nocardiopsis viz., N. synnemataformans, $N$. potens, $N$. prasina and $N$. dassonvillei subsp. albirubida. The molecular identification based on 16S rRNA gene sequences was found accurate and robust. The phylogram generated through multiple sequence alignment of all the test isolates of Nocardiopsis revealed that the isolates aroused from a single branch and validated monophyletic association. The present study is the first report of exploring Nocardiopsis isolates from the dry salt lake. These characterized Nocardiopsis isolates isolated from Didwana dry salt lake habitat are novel stains and can be of significance in the detection and utilization of novel bioactive compounds.
\end{abstract}

Keywords: Actinomycetes, Molecular characterization, Nocardiopsis species, $16 \mathrm{~S}$ rRNA gene

\section{INTRODUCTION}

Actinomycetes are gram-positive filamentous bacteria and are distributed across habitats, including extreme environments. As compared to other Eubacteria, they have a large linear genome with higher Guanine and Cytosine (GC) contents and form an extensively branched mycelium fragmenting into non-motile spore chains (Kampfer, 2006). They are the acknowledged source of bioactive chemical compounds having medicinal and pharmaceutical significance. Berdy (2005) reported that out of the known bioactive microbial metab- olites, 45\% ( 10,000) compounds had been isolated from a various group of actinobacterial species. Out of which, 34\% ( 7600) compounds were from Streptomyces and $11 \%(\sim 2500)$ compounds were from the rare actinobacteria.

Nocardiopsis is one of the most important genera of Actinomycetes group having 62 species (https:// Ipsn.dsmz.de/genus/nocardiopsis) ubiquitously distributed in the environment. Nocardiopsis species are aerobic, Gram-positive, non-acid-fast, catalase-positive with nocardioform substrate mycelia and their aerial mycelia bear long chains of spores. They are halophilic 
or halotolerant in nature and have higher GC contents in their genomic DNA. Their cell walls contain meso 2,6 -diaminopalmelic acid (Kroppenstedt and Evtushenko, 2006). Phospholipid and menaquinones composition are used to distinguish species of Nocardiopsis (Tulskaya et al., 2014). Members of Nocardiopsis has distinctive genetic make-up accumulation of compatible solutes, surfactants and extremozymes allow them to survive under adverse conditions such as hot desert, marine, salterns, mine tailings, hypersaline and alkaline regions (Bennur et al., 2014). Nocardiopsis are known to produce various bioactive compounds such as antibiotics, anticancer substances, tumour inducers, immunemodulators and novel extracellular enzymes (Bennur et al., 2014).

Saline soils of the arid zone are reported to have novel and rare isolates of Actinomycetes (Binayke et al., 2018). It has been found that these rare isolates produce novel bioactive secondary metabolites compounds having a broad range of pharmacological applications (Harwani, 2013). Although various studies have been reported on exploration and identification of Actinomycetes isolates from Rajasthan (Kumar, 2018; Begani et al, 2019) still, review of the literature revealed no comprehensive study on the site of dry salt lake inhabiting Nocardiopsis.

Therefore, the present study was undertaken to isolate and molecularly identify the promising isolates of Nocardiopsis based on culture characteristics, biochemical tests and 16S rRNA gene diversity.

\section{MATERIALS AND METHODS}

\section{Study area}

The dry salt lake of Didwana at Nagaur district of Rajasthan was selected for the exploration of Nocardiopsis isolates. The lake is located in the NE-SW direction (27 $23^{\prime} 46^{\prime \prime} \mathrm{N}$ latitude and $74^{\circ} 33^{\prime} 57^{\prime \prime}$ E longitude) expanded over an area of $10 \mathrm{~km}^{2}$. This lake is mostly dry except few patches of shallow water and is characterized by centripetal drainage without outflow as alkaline brine (Roy et al., 2006).

\section{Collection of soil sample}

The soil samples were collected aseptically from a depth of $5 \mathrm{~cm}$ from the randomly selected locations of dry salt lake, Didwana in airtight plastic bags. The samples were brought to the laboratory and were stored in the refrigerator at $4^{\circ} \mathrm{C}$.

\section{Selective isolation of Actinomycetes isolates}

Air-dried soil samples were kept in an oven at $50^{\circ} \mathrm{C}$ for 24 hours. One gram of soil was suspended in $100 \mathrm{ml}$ of $0.9 \%$ saline solution to prepare stock culture and $0.5 \mathrm{ml}$ of this stock culture was used for serial dilution up to 10 ${ }^{6}$ as suggested by Seong et al. (2001). An amount of
$0.5 \mathrm{ml}$ from this dilution was spread on to Actinobacteria Isolation Agar (AIA) medium supplemented with $0.5 \mathrm{M} \mathrm{NaCl}$. Nalidixic acid $(20 \mu \mathrm{g} / \mathrm{ml})$ and Nystatin $(25$ $\mu \mathrm{g} / \mathrm{ml}$ ) were also added in media to avoid fungal and bacterial contamination. Inoculated petriplates were incubated at $37^{\circ} \mathrm{C}$ for $10-15$ days. The suspected actinobacterial isolates were purified and sub-cultured on Starch Casein Agar (SCA) culture medium for characterization.

\section{Molecular marker based identification Genomic DNA isolation, PCR amplification and 16S rRNA gene sequencing}

Extractions and amplification of genomic DNA of isolated isolates were carried out using protocol from our laboratory (Kumar et al., 2021). The 16S rDNA sequences were amplified using universal forward primer EUB-1 (5' AGA GTT TGA TCC TGG CTC A 3') and reverse primer EUB-2 (5' GCT CGT TGC GGG ACT TAT CC 3'). The purified PCR products were sequenced using Big Dye termination method in $A B I$ prism DNA sequencer.

\section{BLAST search and phylogeny analysis}

$16 S$ rDNA sequences were aligned and subjected to Basic Local Alignment Search Tool (BLAST) search for their similarity analysis. The $16 \mathrm{SrDNA}$ gene sequences were submitted to the GenBank database of NCBI and gene accession numbers were obtained. The phylogenetic tree was constructed using MEGA-7 software (Kumar et al., 2016b). The evolutionary history was inferred using the Neighbor-Joining method developed by Saitou and Nei (1987).

\section{Morphological and biochemical characterization}

Identified isolates of Nocardiopsis were characterized by their phenotypic and biochemical characters using standard methods (Shirling and Gottlieb, 1966; Gordon et al., 1974). The morphological and cultural characteristics of identified isolates were observed by analyzing their growth and colour of aerial and substrate mycelia on AIA and SCA media. Both media were supplemented with $0.5 \mathrm{M} \mathrm{NaCl}$ and incubated at $37^{\circ} \mathrm{C}$. The microscopic features of purified isolates were observed by light microscopy using the cover-slip culture technique (Arifuzzaman et al., 2010) and compared with Bergay's manual of Determinative Bacteriology (Holt et al., 1994). The biochemical characteristics viz., methyl red and Vogues-Proskauer test, degradation of starch, casein, and urea, production of indole and catalase, nitrate reduction and citrate utilization were tested by method described by Cappuccino and Sherman (2004). Utilization of carbohydrates viz., glucose, fructose, rhamnose, mannose, xylose, arabinose, cellobiose, lactose, sucrose and raffinose as carbon source were determined on International Streptomyces Project (ISP) 
medium (Shirling and Gottlieb, 1966).

\section{RESULTS AND DISCUSSION}

A total 18 actinobacterial colonies were isolated on AIA media using serial dilution method. The BLASTn search of 16S rRNA gene sequences of isolates at the National Center for Biotechnology Information (NCBI) web revealed that five isolates belonged to the genus Nocardiopsis (Table 1). The BLAST result further resolved that out of five isolates, two isolates (DW-1 and DW-13) showed more of the $99 \%$ similarity with Nocardiopsis synnemataformans and another three, i.e. DW5 , DW-9 and DW-11 had affinities with different species viz., $N$. potens, $N$. prasina and $N$. dassonvillei subsp. albirubida, respectively, with more than $98 \%$ similarity. The GC values of $16 \mathrm{~S}$ rDNA sequences of these isolates were ranged from 58.31-60.15\%. 16S rRNA gene sequences of these isolates were submitted to GenBank, NCBI to get accession numbers (MT669267, MT669269, MT669270, MT669272 and MT669273).

The morphological and cultural characteristics of the five Nocardiopsis isolates are presented in Table 2. Phenotypic observation and growth pattern of identified isolates were observed on both AIA and SCA media (Fig. 1). The colour of the aerial and substrate mycelia with growth response of all five isolates varied significantly from white, off white, yellow and grey on both selected media. Tiwari et al. (2015) reported the diversity of Actinomycetes isolates by using culture characteristics, including aerial and substrate mycelia, growth patterns, and pigments from the great Indian Thar Desert. Kumar et al. (2016a) used morphological features and biochemical test for the characterization of Streptomyces species in semi-arid soils of Western Rajasthan.

The biochemical and physiological characteristics of all the five isolates are presented in Table 3. Methyl red test and Voges-Proskauer test were performed to differentiate the Actinomycetes isolates on the basis of fermentation of glucose into mixed acids and digestion of glucose into acetyl methyl carbinol, respectively. All the five identified isolates exhibited gram-positive cell wall as distinctive features of Actinomycetes isolates. Out of five isolates, three isolates (DW-9, DW-11 and DW1-3) were positive to methyl red, while three isolates (DW-5, DW-9 and DW-11) were positive to Vogues Proskauer test. Indole test was used to determine the ability of Actinomycetes to split amino acid tryptophan to indole and pyruvic acid using of enzyme tryphophanase. Only one isolate (DW-5) was found positive to indole production test. All the five isolates

Table 1. Molecular characterization of Nocardiopsis isolates.

\begin{tabular}{|c|c|c|c|c|c|c|}
\hline Isolates & Nucleotide & GC (\%) & $\begin{array}{l}\text { Reference } \\
\text { sequence }\end{array}$ & Similarity (\%) & Isolates designation & $\begin{array}{l}\text { GenBank } \\
\text { accession }\end{array}$ \\
\hline DW-1 & 1389 & 58.31 & NR_112742 & 99.78 & $\begin{array}{l}\text { N. synnemataformans } \\
\text { DW-1 }\end{array}$ & MT669267 \\
\hline DW-5 & 1413 & 60.15 & NR_116914 & 99.86 & N. potens DW-5 & MT669269 \\
\hline DW-9 & 1419 & 58.35 & NR_044906 & 99.30 & N. prasina DW-9 & MT669270 \\
\hline DW-11 & 1433 & 59.24 & NR_112743 & 98.95 & $\begin{array}{l}\text { N. dassonvillei subsp. } \\
\text { albirubida DW-11 }\end{array}$ & MT669272 \\
\hline DW- 13 & 1394 & 58.46 & NR_112742 & 99.86 & $\begin{array}{l}\text { N. synnemataformans } \\
\text { DW-13 }\end{array}$ & MT669273 \\
\hline
\end{tabular}

Table 2. Culture characteristics and growth responses of Nocardiopsis isolates.

\begin{tabular}{lllllll}
\hline & \multicolumn{3}{c}{ AlA media } & & SCA media \\
\cline { 2 - 7 } Isolates & $\begin{array}{l}\text { Colour of } \\
\text { aerial } \\
\text { mycelia }\end{array}$ & $\begin{array}{l}\text { Colour of } \\
\text { substrate } \\
\text { mycelia }\end{array}$ & $\begin{array}{l}\text { Growth } \\
\text { response }\end{array}$ & $\begin{array}{l}\text { Colour of } \\
\text { aerial } \\
\text { mycelia }\end{array}$ & $\begin{array}{l}\text { Colour of sub- } \\
\text { strate mycelia }\end{array}$ & $\begin{array}{l}\text { Growth } \\
\text { response }\end{array}$ \\
\hline $\begin{array}{l}\text { N. synnemataformans } \\
\text { DW-1 }\end{array}$ & White & Off white & Good & Off white & Light yellow & Good \\
$\begin{array}{l}\text { N. potens DW-5 } \\
\text { N. prasina DW-9 }\end{array}$ & Yellow & Grey & Poor & Light yellow & Grey & Poor \\
$\begin{array}{l}\text { N. dassonvillei subsp. } \\
\begin{array}{l}\text { albirubida DW-11 } \\
N . \text { synnemataformans } \\
\text { DW-13 }\end{array}\end{array}$ & Grey & White & Poor & White & Off white & Good \\
\hline
\end{tabular}




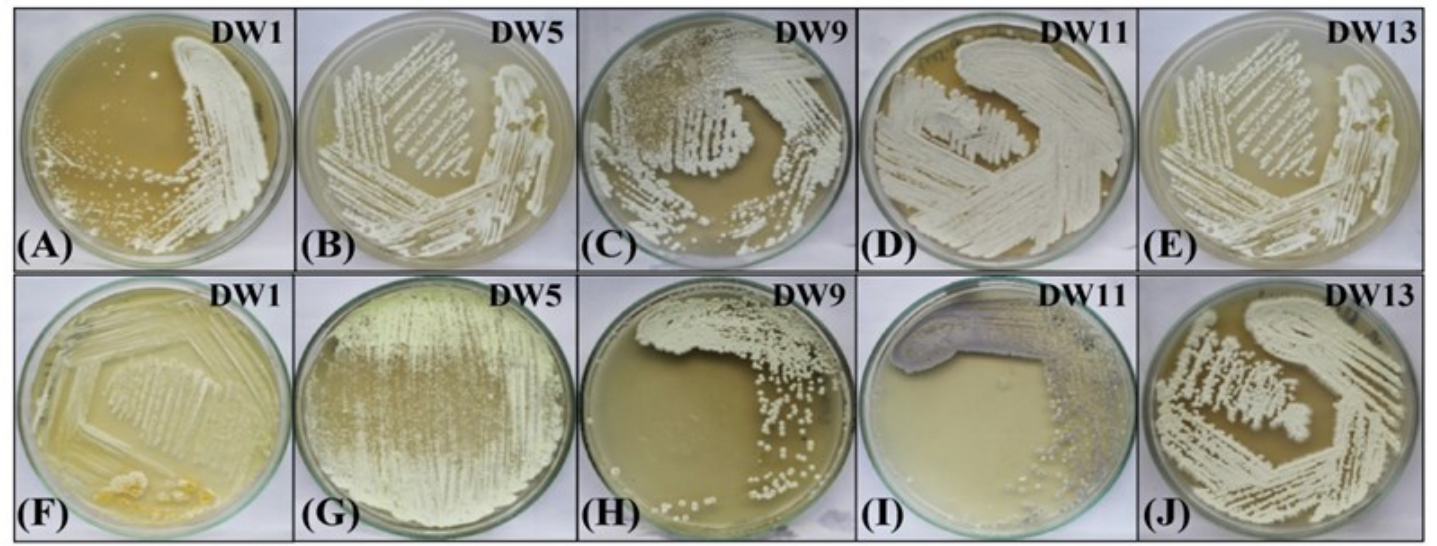

Fig. 1. Growth characteristic of Nocardiopsis isolates on AIA (A to E) and SCA (F to J) media.

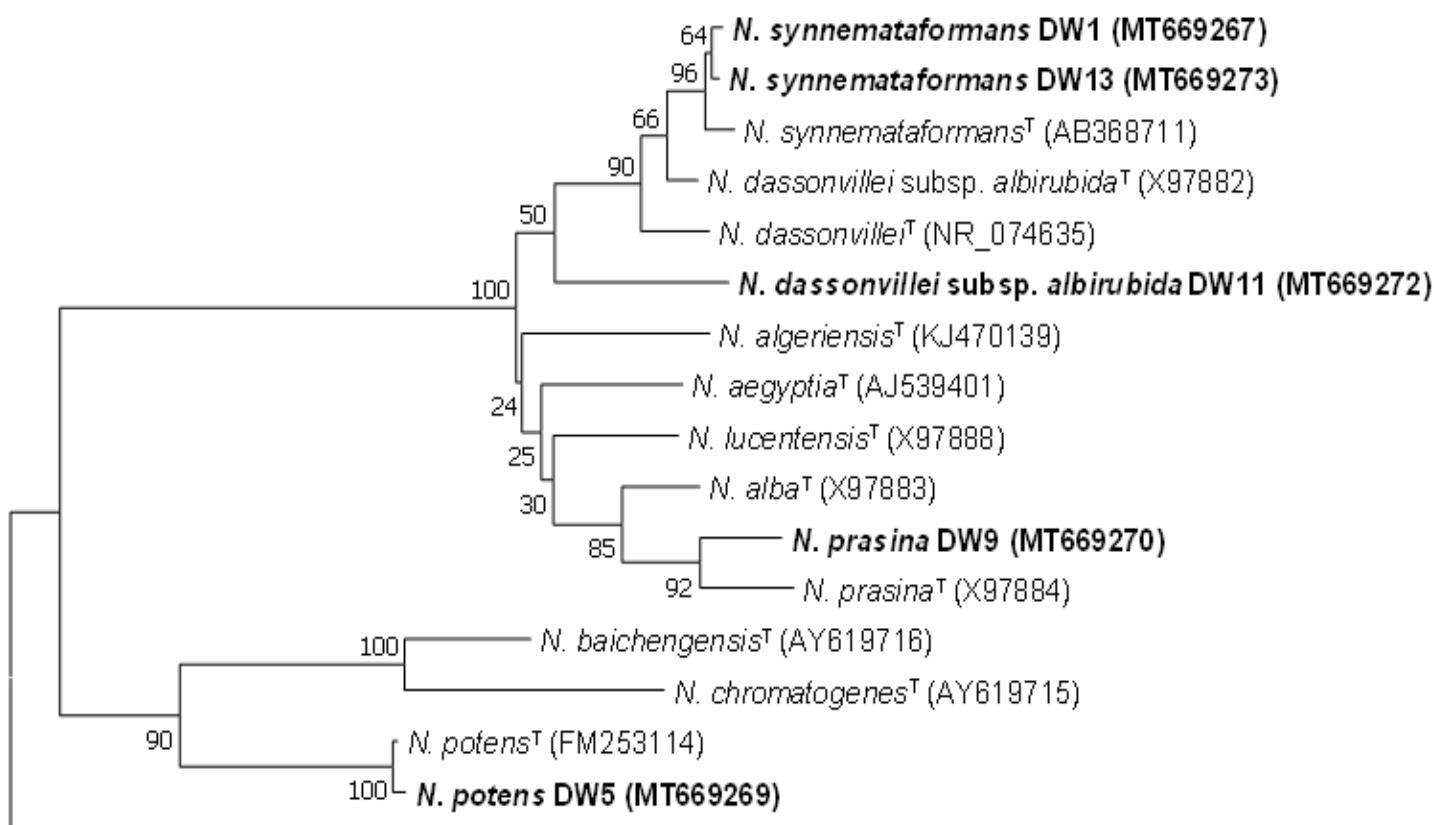

Thermobifida halotolerans ${ }^{\top}$ (NR_044446)

0.0050

Fig. 2. Neighbor-Joining phylogenetic tree of Nocardiopsis isolates using 16S rRNA gene sequences. Tree was constructed with 1000 bootstraps. GenBank accession numbers are in parenthesis.

(DW-1, DW-5, DW-9, DW-11 and DW-13) hydrolyzed starch and casein as they utilized AIA and SCA media for their growth that revealed they produced amylase and protease enzymes. Four isolates (DW-1, DW-5, DW-9 and DW-13) produced urease and citrate enzyme that hydrolyzed urea and citrate salt and converted into end product ammonia, pyruvic acid and $\mathrm{CO}_{2}$, respectively. These four isolates also exhibited catalase enzyme activity as they neutralize toxic forms of oxygen $\left(\mathrm{H}_{2} \mathrm{O}_{2}\right)$ metabolites. Three isolates viz., DW-1, DW-5and DW-13 exhibited nitrate reductase activity as they hydrolyzed nitrate $\left(\mathrm{NO}_{3}{ }^{-}\right)$to nitrite $\left(\mathrm{NO}_{2}{ }^{-}\right)$. The carbon utilization ability of all the isolates varied significantly exhibiting their ability to ferment different carbo- hydrates. Kumar et al. (2016a) studied biochemical parameters of Streptomyces isolates isolated from western Rajasthan and advocated that biochemical traits are strain-specific rather than species traits. The phylogenetic tree of characterized Nocardiopsis isolates using the multiple sequence alignment with high bootstrap values indicated a close phyletic line with distinct clades. It delineated all the five isolates from each other along with closeness of phylogenetic relations (Fig.2).The Nocardiopsis isolates delineated into two main clusters. Cluster I included only one isolate $N$. potens DW-5 while cluster II included four isolates $\mathrm{N}$. synnemataformans DW-1, N. synnemataformans DW- 
Table 3. Biochemical and physiological characteristics of Nocardiopsis isolates.

\begin{tabular}{|c|c|c|c|c|c|c|}
\hline \multirow[b]{2}{*}{ Characteristics } & & \multicolumn{5}{|c|}{ Isolates } \\
\hline & & $\begin{array}{l}\text { N.synnemataf } \\
\text { ormans DW-1 }\end{array}$ & $\begin{array}{l}\text { N.potens } \\
\text { DW-5 }\end{array}$ & $\begin{array}{l}\text { N.prasina } \\
\text { DW-9 }\end{array}$ & $\begin{array}{l}\text { N. dassonvil- } \\
\text { leisubsp. al- } \\
\text { birubida } \\
\text { DW-11 }\end{array}$ & $\begin{array}{l}\text { N.synnemata } \\
\text { formans DW- } \\
13\end{array}$ \\
\hline \multirow[t]{9}{*}{ Biochemical test } & Methyl Red & - & - & + & + & + \\
\hline & Voges-Proskauer & - & + & + & + & - \\
\hline & Indole Production & - & + & - & - & - \\
\hline & Citrate Utilization & + & + & + & - & + \\
\hline & Nitrate reductase & + & + & - & - & + \\
\hline & amylase & + & + & + & + & + \\
\hline & Protease & + & + & + & + & + \\
\hline & Urease & + & + & + & - & + \\
\hline & Catalase & + & + & + & - & + \\
\hline Carbon & Glucose & + & + & + & + & + \\
\hline \multirow[t]{9}{*}{ utilization test } & Fructose & - & + & + & + & + \\
\hline & Rhamnose & + & - & - & + & + \\
\hline & Mannose & + & + & + & - & + \\
\hline & Xylose & + & - & - & + & + \\
\hline & Arabidose & - & - & + & + & - \\
\hline & Cellobiose & + & + & + & + & + \\
\hline & Lactose & - & + & - & - & - \\
\hline & Sucrose & - & + & - & + & - \\
\hline & Raffinose & - & - & - & + & - \\
\hline
\end{tabular}

(+ = positive response, $-=$ negative response)

13, N. dassonvillei subsp. albirubida DW-11 and $N$. prasina DW-9, indicating the presence of genetic variability within the genus. This may be attributed to the single nucleotide polymorphisms (SNPs) in 16S gene region during the process of evolution by insertion, deletion or substitution (López-Pérez et al. 2014; SantosBeneit, 2018).

\section{Conclusion}

The present study is the first report of exploring Nocardiopsis species from the dry salt lake of Didwana, Rajasthan, which resulted in identifying four Nocardiopsis species with five distinct isolates viz. N.synnemataformans, $N$. potens, $N$. prasina and $N$. dassonvillei subsp. albirubida. These promising Nocardiopsis isolates isolated from unusual habitat can be sources for novel bioactive compounds for industrial and therapeutic use.

\section{ACKNOWLEDGEMENTS}

The first author is thankful to University Grant Commission (UGC), New Delhi for financial support in the form of JRF.

\section{Conflict of interest}

The authors declare that they have no conflict of interest.

\section{REFERENCES}

1. Arifuzzaman, M., Khatun, M.R. and Rahman, H. (2010). Isolation and screening of actinomycetes from Sundarbans soil for antibacterial activity. African Journal of Biotechnology, 9 (29), 4615-4619.

2. Begani, J., Lakhani, J. and Harwani, D. (2019). A broad spectrum antimicrobial activity of thermophilic Nocardiopsis sp. producing multiple extracellular enzymes of industrial and theupeutic use. Asian Journal of Pharmacy and Pharmacology, 5 (3), 525-534. https://doi.org/1 0.31024/ajpp.2019.5.3.14

3. Bennur, T., Kumar, A.R., Zinjarde, S. and Javdekar, V. (2014). Nocardiopsis species as potential sources of diverse and novel extracellular enzymes. Applied Microbiology and Biotechnology, 98 (22), 9173-9185. https:// doi.org/10.1 007/s00253-014-6111-y

4. Berdy, J. (2005). Bioactive microbial metabolites: A personal view. Journal of Antibiotics, 58: 1-26.https:// doi.org/10.1038/ja.2005.1

5. Binayke, A., Ghorbel, S., Hmidet, N., Raut, A., Gunjal, A., Uzgare, A., Patil, N., Waghmode, M. and Nawani, N. (2018). Analysis of diversity of actinomycetes from arid and saline soils at Rajasthan, India. Environmental Sus- 
tainability, 1(1), 61-70. https://doi.org/10.1007/s42398-018 $-0003-5$

6. Cappuccino, J.C. and Sherman, N. (2004). Microbiology: A laboratory manual. Pearson Education, Inc., New Delhi.

7. Gordon, R.E., Barnett, D.A., Handerhan, J.E. and Pang, C.H.N. (1974). Nocardiacoeliaca, Nocardiaautotrophica, and the Nocardin strain. International Journal of Systametic and Evolutionary Microbiology, 24(1), 54-63.https:// doi.org/10.1099/00207713-24-1-54

8. Harwani, D. (2013). Biodiversity of rare thermophilic actinomycetes in the great Indian Thar desert: an overview. Indo American Journal of Pharmaceutical Research, 3 (11), 9349-9356.

9. Holt, J.G., Krieg, H.R., Sneath, P.H.A., Stacey, J.T. and Williams, S.T. (1994). Bergey's Manual Sergey's Manual of Determinative Bacteriology, 9th (Ed.). Williams \& Wilkins Co., Baltimore, Maryland.

10. Kampfer, P. (2006). The family Streptomycetaceae, part I: taxonomy. The prokaryotes: an evolving electronic resource for the microbiological community. SpringerVerlag, New York, pp 538 -604. https://doi.org/10.1007/0387-30743-5 22

11. Kroppenstedt, R.M. and Evtushenko, L.I. (2006). The family Nocardiopsaceae. The prokaryotes: a handbook on the biology of bacteria. Springer-Verlag, New York, pp 754795.https://doi.org/10.1007/0-387-30743-5 29

12. Kumar, S. (2018). Note on Nocardiopsis synnemataformans ITD-3 Isolated from Indian Thar Desert. Plant Archives, 18 (1), 815-816.

13. Kumar, S., Priya, E., Solanki, D.S., Sharma, R., Gehlot, P., Pathak, R. and Singh, S.K. (2016a). Occurrence and characterization of hitherto unknown Streptomyces species in semi-arid soils. Journal of Environmental Biology, 37, 927-936.

14. Kumar, S., Solanki, D.S., Parihar, K., Tak, A., Gehlot, P., Pathak, R. and Singh, S.K. (2021). Actinomycetes isolates of arid zone of Indian Thar Desert and efficacy of their bioactive compounds against human pathogenic bacteria. Biologia Futura. https://doi.org/10.1007/s42977-02100073-5.

15. Kumar, S., Stecher, G. and Tamura, K. (2016b). MEGA7: molecular evolutionary genetics analysis version 7.0 for bigger datasets. Molecular Biolology and Evolution, 33 (7), 1870-1874.https://doi.org/10.1093/molbev/msw054

16. López-Pérez, M., Martin-Cuadrado, A.B. and RodriguezValera, F. (2014). Homologous recombination is involved in the diversity of replacement flexible genomic islands in aquatic prokaryotes. Frontiers in Genetics, 5, 147. https:// doi.org/10.3389/ fgene. 2014.00147

17. Roy, P.D., Smykatz-Kloss, W. and Sinha, R. (2006). Late Holocene geochemical history inferred from Sambhar and Didwana playa sediments, Thar Desert, India: comparison and synthesis. Quaternary International, 144, 84-98. https://doi.org/ 10.1016/ j.quaint.2005.05.018

18. Saitou, N. and Nei, M. (1987). The neighbor-joining method: a new method for reconstructing phylogenetic trees. Molecular Biology and Evolution, 4 (4), 406-425.

19. Santos-Beneit, F. (2018). Genome sequencing analysis of Streptomyces coelicolor mutants that overcome the phosphate-depending vancomycin lethal effect. $B M C$ Genomics, 19, 457.https://doi.org/10.1186/s12864-0184838-z

20. Seong, C.N., Park, J.H. and Baik, K.S. (2001). An improved selective isolation of rare actinomycetes from forest soil. J. Microbiol., 39, 17-23.

21. Shirling, E.T. and Gottlieb, D. (1966). Methods for characterization of Streptomyces species. International Journal of Systametic and Evolutionary Microbiology, 16 (3), 313340.https://doi.org/10.1099/00207713-16-3-313

22. Tiwari, K., Upadhyay, D.J., Mösker, E., Süssmuth, R. and Gupta, R.K. (2015). Culturable bioactive actinomycetes from the great Indian Thar Desert. Annals of Microbiology, 65 (4), 1901-1914. https://doi.org/10.1007/s13213-014 $-1028-3$

23. Tulskaya, E.M., Shashkov, A.S., Streshinskaya, G.M., Potekhina, N.V. and Evtushenko, L.I. (2014). New structures and composition of cell wall teichoic acids from Nocardiopsis synnemataformans, Nocardiopsis halotolerans, Nocardiopsis composta and Nocardiopsis metallicus: a chemotaxonomic value. Antonie van Leeuwenhoek, 106 (6), 1105-1117.https://doi.org/10.1007/s10482-014-0280-7 